\title{
Jehovah's Witnesses' Three Periods
}

\author{
By ÅKE STRÖM
}

Among modern formations of religion, arisen within Christendom, ${ }^{1}$ there is no one that has changed its doctrine and attitude so much as Jehovah's Witnesses, so that the religious content in the three periods can be labelled as new, newer, the newest. Each period is connected with and dependent upon the three presidents Charles Taze Russel, born in 1852, president 18811916, Joseph Franklin Rutherford, born in 1869, president 1916-1942, and Nathan Homer Knorr, born in 1905, president from 1942. My purpose is to clarify some important differences between the three periods not observed in the literature ${ }^{2}$ but very important both for a scientific study of the movement and for honest polemics in order to avoid antiquated arguments.

\section{The Russel Period}

Already in Russell's own autobiographical report about his attendance at an adventist meeting in 1868 there is a characteristic feature of intellectualism when he says: "I wanted to notice, if the few ones gathered there had anything more reasonable to offer than the creeds of the large churches." 3 Four years later he undertook to "enquire into the doctrine of restoration". ${ }^{4}$ In Russell's standard work we find a large number of intellectualistic headings, e.g., "The Existence of a Supreme Intelligent Creator Established", "A Divine Revelation Viewed in the Light of Reason" and "The Fact and

\footnotetext{
${ }^{1}$ See e.g. the short survey in Ringgren, $169 \mathrm{ff}$.

${ }^{2}$ So McKinney occasionally uses outdated quotations from earlier periods, while Hoekema shortly mentions the three epochs, $223 \mathrm{ff}$, but gives full description only of the last one, $233 \mathrm{ff}$. Skjerpe and other Scandinavian authors mingle the three periods. The official history of the movement, Jehovah's Witnesses, refer to Russell's and Rutherford's books, as well as the later publications.

${ }^{3}$ Russell 1921, 72. NB. As it has been impossible to get hold of this one and several later Jehovah's witnesses' books in English, since they are not to be found in Swedish libraries or available in the Watch Tower book shops in Sweden and in Denmark, I must in many cases rest content with retranslating the Swedish version into English.

${ }^{4}$ Russell 1921, 73.
} 
Philosophy of the Aronement". ${ }^{5}$ His production and the whole tendency of the movement can be said to be apocalyptic of a quasi-intellectual character, based on an allegorical interpretation of the Scriptures and on a complicated arbitrary mathematical system for computing the end of the world near at hand. ${ }^{6}$

Russell developed a biblical chronology with 6000 years from the creation of Adam to the Russellian year $1872^{7}$ and fixed the end of "The Times of the Gentiles" to $1914,{ }^{8}$ when "Christ's Kingdom / will be/ fully established". ${ }^{9}$ The whole divine plan of the ages is demonstrated to be prefigured in the great pyramid of Gizeh in Egypt, which is said to be "God's stone witness and prophet"10 — a subject which was developed in a work in two volumes by John \& Morton Edgar, the 2 nd of which was translated into Swedish by Hugo Karlén in 1915. We find e.g. the history up to the year 1915 A.D. prefigured. ${ }^{11}$

The allegorical method used by Russell sees the steem-engine in Behemoth and the locomotive engine in Leviathan (Job, ch. 40 f) ${ }^{12}$ and finds in Revelation chapt. 18 " the glories of the new age, all discovered or invented since 1874 ' 13 . All these new things are registered in alphabetical order, e.g. under $A$ : aluminium, antiseptic surgery, automatic couplings, and under $S$ : separators, shoe-stitching machines, sky-scrapers, the South Pole, settingmachines. ${ }^{14}$

\footnotetext{
5 Russell 1954 f, 1, 29, and 37; 5, 15. denborg and Mrs Ellen White cf. Ringgren, $171 \mathrm{f}$. (cf. Rutherford 1923, 229; Låt Gud 1950, 207; 1963, 213).

${ }^{8}$ Cf. Russell 1954 f, 2, 76; 3, 23.

${ }^{9} \mathrm{Ib} .2,170$.

10 Ib. 3,313 , cf. ib. $313 \mathrm{ff}$.

11 Cf. Edgar, 249.

12 Cf. Russell 1921, $114 \mathrm{ff}$.

13 Ib. 383.

14 The same things are enumerated by Rutherford 1923, 224.
}

6 This fact stands in sharp contrast to the conditions of the Mormons, who are the heirs to Delaware Indian religion, who are interested in history, and whose movement is based on a prophet's visionary experience, cf. Ström 1969, $120 \mathrm{ff}$. About Russell's forerunners E. Swe-

7 Cf. Russell 1954f, 2, 33 and 42. The year 1872 is here and in later books, e.g. Lät Gud, 1950,$207 ; 1963,213$, said to be the vital point of chronology: "Since 1872 A.D. we are chronologically entered upon the seventh thousand or the Millennium" $(2,33)$, but in the same volume 170 we read: " 1874 A:D. was the exact date of the beginning of the 'Times of Restitution', and hence of our Lord's return". - In the same way "The Watch Tower Bible and Tract Society" is sometimes said to be registered in Pennsylvania in 1881 (cf. Knorr, 382), sometimes in 1884 
Russell mentions "assembling" and "meetings" of the Lord's people, which are "left free in the exercise of the spirit of a sound mind, left free to seek the wisdom that cometh from above" ${ }^{15}$ At these meetings he recommends four things: (1) instruction in prophetical matters and the moral doctrines, (2) opportunity to express defective understanding, (3) opportunity for anyone to present a different point of view, (4) "devotional services connected with all meetings' ${ }^{16}$

For the last mentioned purpose, 333 hymns were selected in 1902 to form a hymn book called "Hymns of Dawn" and arranged in strict alphabetical order, with an Introduction by C. T. Russell. The hymnbook was enlarged in 1909 with 337 numbers and called "Hymns of the Millennial Dawn". A collection of hymns in Swedish, called "Morgonsånger", with 166 hymns, 65 of which were translated from the Hymns of Dawn, appeared in 1909 and was extended to 300 numbers in 1921, fourteen being added from Hymns of Dawn.

Most of the hymns in these collections stress the love and salvation of Jesus and the ardent love of the faithful towards him. Many of them are well known, written by such hymnologists as Paul Gerhardt, N. L. von Zinzendorf, Augustus M. Toplady, Sarah Adams, and Lydia Baxter, ${ }^{17}$ e.g. "Nearer, my God, to Thee, Nearer to Thee"' (nr. 188) and "There is a gate that stands ajar" (nr. 291). The only ground of salvation is said to be Jesus:

My hope is built on nothing less

Than Jesus' blood and righteousness.

I dare not trust the sweetest frame, but wholly lean on Jesus' name.

Chorus:

On Christ, the Solid Rock, I stand;

all other ground is sinking sand. (Nr. 178:1)

The hope of a blessed eternity is also founded on Jesus:

Farewell, mortality!

Jesus is mine!

Welcome, eternity!

Jesus is mine!

\footnotetext{
15 Russell 1954 f, 6, 309 and 312.

16 Ib., 314.

${ }^{17}$ Hymns, Nos. 57, 90, 106, 141, and 251.
} 
Welcome, ye scenes of rest!

Welcome, ye mansions blest!

God's love is manifest

Jesus is mine! (Nr. 47:4)

In the Swedish hymnbook "Morgonsånger" we find a remarkable Christmas Carol:

Guds egen son på krubbans strå väl änglarna i häpnad stå på denna stora dag
God's only son is laid on straw. The angels stand in holy awe on this magnificant day.

(Nr. 33:1)

About Jesus' life we don't hear so much, but the cross is very often spoken of in the hymns (Nrs. $5: 4 ; 15 ; 123: 1 ; 135 ; 295 ; 312$ with the chorus: "Only Jesus will I know / And Jesus crucified", 325 "When I survey the wondrous cross / On which my blessed Saviour died", 18326 and others) and also of his resurrection (Nrs. 31; 169:3). A faithful man can be spoken of as "a soldier of the cross" (13:1) and is able to join in the chorous:

Jesus died for you, and Jesus died for me.

Yes, Jesus died for all mankind.

Praise [1909: Bless] God! Salvation's free. (Nr. 5)

In "Morgonsånger", we have also hymns of affection to Jesus-e.g. Nrs. 23 and 75, with reflections about the cross in Nrs. 33, 151, and 244.

Baptism is accompanied with a hymn that would fit into the ritual of any church:

\author{
Come, Jesus, Master, Sun Divine! \\ On these baptismal waters shine. \\ Thy light, thy love, thy life impart, \\ and fill each consecrated heart. (Nr. 33:1)
}

On the theme of the church we meet not only Samuel J. Stone's old oecumenical hymn “The church's [1909: Church's] one foundation / Is Jesus Christ, her Lord" (Nr. 281:1) but also a prophecy about the church and the nations:

\footnotetext{
18 This hymn by Mrs C. T. Russell is not to be confused with the Anglican hymn with the beginning identical in wording.
} 
On Thy Church, o Power [1909: Pow'r] divine! cause thy glorious face to shine, till the nations, from afar, hail her as their guiding star... and the world's remotest bound with the voice of praise resound. (Nr. 217:1-2)

\section{The Rutherford Period}

Judge Rutherford, who was elected president after Russell's death and who had rescued the movement after the failure of Russell's prophecy about the Reign of Peace in 1914 by pointing out that Christ had come this year invisibly to the Government in heaven, ${ }^{19}$ dinstinctly altered the spiritual direction of the movement. In his funeral speech in honour of Russell during the evening service he praised Russell as "the greatest man that has lived since the apostle Paul", ${ }^{20}$ but after a sharp fight ending with an election victory for the supporters of the Rutherford line ${ }^{21}$ it could be seen that Rutherford differed from Russell especially on the following five points:

1. The name of God. Russell always speaks of the Almighty as God or the Lord. But when Rutherford edits Russell's posthumous work: "Studies in the Scriptures" 7, in 1917, he inserts the Old Testament name Jehovah, ${ }^{22}$ and uses this name more and more in his own writings. As early as in 1922 Rutherford in an address given at an assembly in Cedar Point, Ohio, used a word from Isiah 43: 12: "You are my witnesses says Jehovah, and I am God", where King James" version has "saith the Lord", and in a huge international assembly in Columbus, Ohio, July 26, 1931 a resolution was adopted, that "we desire to be known as, and called by the name, to wit, Jehovah's witnesses". ${ }^{23}$

2. The view of the state. Studies in the Scriptures 7 is a commentary on the book of Revelation, the Song of Solomon and Ezekiel, collected from Russell's works. In them, Russell demonstrates that the two beasts in Rev. 13 are the Roman Catholic Church and the Church of England. ${ }^{24}$ But in 1930 Rutherford is bold enough to state that no satisfactory interpretation of

\footnotetext{
19 Cf. Rutherford, 1923, 233, and Hoekema, 298, note 402.

20 Rutherford 1916, 373.

${ }^{21}$ Cf. The Watch Tower 1916, 383, 1917, 327 ff. $371 \mathrm{ff}$; Hoekema, $228 \mathrm{f}$.

${ }^{22}$ Cf. e.g. Russell 1921, 522, 527642,657 , and 779.

${ }^{23}$ Babylon, 466; cf. ib. 464 ff.

${ }^{24}$ Cf. Russel 1921, 268 ff.

10-752446 H. Biezais
} 
Revelation exists up to that year, ${ }^{25}$ and so he gives one, where the first beast is said to be Satan's Organization, i.e. the political and ecclesiastical order, ${ }^{26}$ the second one is "the Anglo-American imperialism", ${ }^{27}$ and the image of the beast (Rev. 13: $14 \mathrm{f}$ ) is the League of Nations. ${ }^{29}$

The same view of the state but with other Biblical metaphors is to be found as early as in 1921, when Rutherford gave the following exegesis of the passage about the passing of heaven and earth (2 Pet. 3: 10): "The heavens represent the invisible government power, that consists of Satan and his invisible servants [...] The earth represents the organized society under Satan's overdominion." 29

The thought of the very state, even the democratic, as Satan's incarnation then returns in Rutherford's whole production. ${ }^{30}$ To hoist or salute a flag is to serve Satan. ${ }^{31}$

3. The word religion changed its meaning in Rutherford's language. Early he could say, that Jehovah founded the true religion on earth, which consists in glorifying his name. ${ }^{32}$ But from 1926 the word religion is only connected with Satan, ${ }^{33}$ because Christianity and religion are quite different and opposite terms. ${ }^{34}$

Lastly we get the definition: "Religion is practised, when anything is done contrary to the will of God Almighty." "35 That is why God Jehovah condemns religion as being a work of the devil and a means to deceive men. ${ }^{36}$

4. Jesus is said to have died on a cross, ${ }^{37}$ as also stated by Russell. A brusque picture of Jesus nailed on a quite ordinary cross is to be found in

${ }^{25}$ Cf. Rutherford 1930. 1, $5 \mathrm{f}$.

${ }^{26}$ Cf. ib., 270ff. A coherent treatise on Satan's organisation is given in Rutherford 1929, $121 \mathrm{ff}$.

${ }^{27}$ Rutherford 1930, $293 \mathrm{ff}$.

${ }^{28} \mathrm{Cf}$. ib., $306 \mathrm{ff}$.

${ }^{29}$ Rutherford 1923, 240.

${ }^{30}$ Cf. Rutherford 1932, 149; 1942, 19.

${ }^{31}$ Cf. Rutherford $1941 a, 31$. To salute the American flag is still all right according to The Watch Tower, 1917, 150, where it is said: "Thank God for the privilege of living in the United States!"

${ }^{32}$ Cf. Rutherford 1923, 53.

${ }^{33}$ Cf. Rutherford 1926, 38.

${ }^{34}$ Cf. Rutherford 1931 b, 134 f; 1942, 44.

35 Rutherford 1941 b, 19.

${ }^{36}$ Cf. ib., 19 f.

${ }^{37}$ Cf. Rutherford 1923, 136; 1926, $146 \mathrm{f}$. 
Rutherford's most authoritative handbook. ${ }^{38}$ But on the cross Jesus gave his life as a big ransom price demanded by Divine Justice in heaven. ${ }^{39}$ Besides this Jesus is our teacher, ${ }^{40}$ and as "God's executing officer" or the "executing officer of the Theocracy" ${ }_{41}$ he is "Jehovah's executioner", 42 who will personally put to death all disobedients and apostates. ${ }^{43}$ In the battle of Armageddon "Jesus Christ, the blood-avenger, shall kill the malignant clergymen and pastors and their confederates". ${ }_{44}$

5. Class division. Russell speaks in a passage very generally about "two degrees or kinds of heavenly salvation and two degrees or kinds of earhtly salvation". ${ }^{45}$ Rutherford gradually develops many classes according to different situations and Bible passages. Jehu, whose name looks like Jehovah, is a symbol of the class of the 144000 witnesses (Rev. 7:4) and his assistant Jehonadab, who had to take a seat in the chariot (II Kings 10:15f), and Jonathan symbolize the class of the "great multitude" (Rev. 7:9) or "the other sheep" (John 10:16). ${ }^{46}$ Further the Naomi class (of oppressed widows) is spoken of as well as the Ruth class (orphans), ${ }^{47}$ the class of the nearest kinsman (repurchaser, Ruth $4: 1$ ), ${ }^{48}$ we have the Mordecai class, who according to Esther chapter 2 served Jehovah and his people from the second coming of the Lord in 1914 to the year $1919 .{ }^{49}$ Other often mentioned classes are "the class of the bad servant" (Math. 24:4851 ), which consists of apostates, ${ }^{50}$ and "the dreamer class", the old dreaming men (Joel 2:28) who today hold the opinion, that "all God's truth was revealed through one single man [=Russell] before October 1916" ${ }^{51}$ These Free Bible Students, in Sweden called old-Russellians, were dissatisfied

${ }^{38}$ Cf. the whole page in Rutherford 1923, 110. Cf. the coloured picture in Rutherford 1931, 265.

${ }^{39}$ Cf. Rutherford 1923, 132; 1926, $171 \mathrm{f}$.

40 Cf. Rutherford 1931 a, 276; 1932, 260.

${ }^{41}$ Rutherford 1929, 241; 1931 a, 276; 1942, 77.

42 Rutherford 1942, 255.

43 Cf. Rutherford 1942, 328.

${ }^{44}$ Rutherford 1938, 113.

45 Russell 1921, 184. About that cf. Hoekema, 288.

${ }^{46}$ Rutherford 1942, 105. About the sociology of the rutherfordian period cf. Ström 1946, $82 \mathrm{ff}$.

47 Cf. Rutherford 1932, 316.

${ }^{48}$ Cf. ib., 307.

49 Cf. ib., 45.

${ }^{50}$ Cf. Rutherford 1930, 1, 270; 1932, 310; 1942, 25, 250, and 322.

${ }^{51}$ Rutherford 1942, 240. 
with Rutherford on account of his holding the Gizeh pyramid to be not the work of God but of Satan. ${ }^{52}$ They were dismissed by Rutherford ${ }^{53}$ but exist still as schismatic groups, a Swedish remnant group meet in Bromma under the presidency of Anders Karlén, a son of the above mentioned Hugo Karlén, who translated a work on the pyramid. ${ }^{54}$

\section{The last period}

The present president, Nathan H. Knorr, once more changed the direction of the movement, this time for the main part away from Rutherford to greater accordance with Russell. The biased political tendency is gone as is Russell's mathematical apocalyptic. A speciality is to be observed: all books published are anonymous and not one of the articles in the Watch Tower is under-signed. Let us take a look at the above mentioned vital points:

1. The name of God is still Jehovah, but it is once again withdrawn in favour of God. In the lates books, "The Nations shall know that I am Jehovah-How?", 1971, 3. "True Peace and Security-From what Source?"' edited 1973, “'and God's Kingdom of a Thousand Years Has Approached", 1973, the name God is most often used, now and then "Jehovah God", and we find often 'The Lord' (Swedish: HERREN as the name of God.

2. The view of the state is altered. Of special interest here is the book of fundamental dogmatics, "Let God be True", where we have a chapter on state, flag and politics. ${ }^{55}$ Here is stressed the fact that just as ambassadors of a state are exempted from taxes and political duties against the foreign power, so the emissaries of Jehovah are exempted from military service, although they "are not religious, political or ethical pacifists", and from saluting or paying homage to a flag, since that would be idolatry. ${ }^{56}$

"The 'authority' mentioned in Romans 13, 1-5", we read, "are the principal governing factors in the community of God Almighty" and are not "to be applicable to rulers in this bad world, guided by Satan [...] The 'authority' [. . .] is Jehovah God and Jesus Christ". ${ }^{57}$ And it is stressed,

${ }^{52}$ Cf. Rutherford 1930, 1, 12;2, 63 and 284.

${ }^{53}$ Cf. Hoekema, $228 \mathrm{f}$.

${ }^{54}$ Cf. Ståhl, 68 ff.

${ }^{55}$ Cf. Låt Gud 1950, $221 \mathrm{ff}$.

${ }^{56} \mathrm{Cf}$. ib., 224 and $228 \mathrm{f}$.

${ }^{57} \mathrm{Ib} ., 235$. So also Rutherford $1941 a, 31$. 
quite against Rutherford, that Jehovah's witnesses "have regard for the good principles represented by the flag of the nation in which they live", and that the witnesses "are not against paying homage or wishing to pay homage to the flag of a nation"..$^{58}$

In the 2 nd revised edition of 1952 the development goes further. The same chapter is now called "Cæsar's Things to Cæsar" (Math. 22:21) and is rewritten in a style more like that of the New Testament. The witnesses are now not "exempted" but have an "exceptional position", 59 and it is emphasized that they are "law-abiding". ${ }^{60}$ It is acknowledged that in Rom. 13 there is spoken of "the political authority", which, however, "has only right to a relative subjection on the part of the Christians, restricted by the Christian consciousness' ${ }^{61}$ - that is to say exact the position held by the Church during the Hitler period. The new Watch Tower Bible translation renders Rom. 13: 1b this way: "The existing authorites stand placed in their relative positions by God." 62

3. The word religion regained its usual meaning through a long semantic exposition in 1951, where it is said: "Though all other kinds disagree with it, there must be only one kind of worship, one religion, that is right." ${ }^{\prime 3}$ In the following chapters there is an analysis of the only right religion and of the false one. ${ }^{64}$

4. Jesus dies no longer on a cross, which is considered to be a heathen sun-symbol or the Egyptian life-symbol, introduced by Constantin's Milano-edict in 312 A.D. Jesus, on the contrary, was put to death on a simple pole or torture stake, and "to use crosses in devotion is idol worship" ${ }^{65}$ In the great Biblical history "From Paradise Lost to Paradise Regained", 1958, there is a whole-page picture showing Jesus and the two thieves on the torture poles. ${ }^{66}$

On the other hand in this latest period there is no speaking of Jesus as an executioner or blood-avenger. Once it is said casually in an early volume: “Jehovah's messengers are not authorized by him to act as executioners.

${ }^{58}$ Làt Gud 1950, 232.

59 Låt Gud 1963, 229.

60 Ib., 237.

61 Ib., 239.

62 Cf. King James' version; "The powers that be are ordained of God".

63 What Has Religion, 16.

${ }^{64} \mathrm{Cf} . \mathrm{ib}, \mathrm{f3} \mathrm{ff}$.

65 Skaffa eder, $234 \mathrm{f}$.

${ }^{66}$ Paradiset, 141. Cf. Utsagor, 215 and 235. 
His principle executing officer, Christ Jesus, [. . .] will do the destroying work", ${ }^{67}$ and this subject is dealt with at some length in a later book. But still later on it is God, who is said to be "the Avenger of blood".

5. The class division, finally, seems to be forgotten. It is totally missed in all the Indexes of subjects. The only class mentioned is "the faithful and discernable servant",${ }^{68}$ a class made up of the witnesses themselves.

All this could look like a restitution of Russell's ideas. But there are great differences between Russell's mathematic and apocalyptic intellectualism, combined with passionate love for Jesus, and the nowaday's cool systematic doctrine of history. Christmas and Easter are not to be celebrated. ${ }^{69}$ The apocalyptic scheme is very thin and poor, concentrated to a few crucial points, e.g. the years $70,1914,1918$ and $1963 . .^{70}$

We find to-day an almost incredible interest in archeology, literary criticism, exegesis, history and linguistics in order to strengthen the own ideas and used as long as those sciences are suitable for promoting the message. An early hand-book of Biblical isagogies, "Equipped for Every Good Work", 1946, which quotes the Dead Sea scrolls, the Papyrus Nash, and other contemporary sources and discusses the various codices, ${ }^{71}$ is completed by a more comprehensive work, "All Scripture is Inspired by God and Beneficial," 1963. Not only all Papyrus and Vellum Bible manuscripts are registered and characterized ${ }^{72}$ but also the archeological parallels such as the Mesha stone and the Tiberius stone slab, found in Caesarea in $1961 .^{73}$

Other most instructive learned works of limited size and in popular stile are the handy encyclopaedia "Make Sure of All Things", revised in 1957, where 70 themes are elucidated by passages of Scripture, with commentaries only given in the headings, further "The Truth that Leads to Life", 1968, an abstract of the Watch Tower doctrine, and finally "Is the Bible Really the Word of God?", 1969, the authors of which try to support

\footnotetext{
${ }^{67}$ Låt Gud 1950, 234; 1963, 238.

68 Utsagor, $339 \mathrm{f}$.

${ }^{69} \mathrm{Cf}$. What Has Religion, 234.

${ }^{70}$ Cf. Skaffa eder, $84 \mathrm{f}$; All Scripture, 231, 346. In a commentary to Daniel the authors at some length give the history of the western modern empires and of the Watch Tower movement intermingled (Your will, $176 \mathrm{ff}$ ).

${ }^{71} \mathrm{Cf}$. Gott verk, $46,55 \mathrm{ff}$.

${ }^{72}$ Cf. All Scripture, $304 \mathrm{ff}$.

${ }^{73}$ Cf. ib., 331.
} 
biblical statements by means of quotations from contemporary sources such as Assyrian and Egyptian inscriptions, Tacitus, Celsos, Josephus etc. ${ }^{74}$ and arguments by scholars like Fred Hoyle, Hannes Alfvén, A. T. E. Olmstead, J. Klausner, W. F. Albright, and Paul Ehrlich. ${ }^{75}$

A hymnbook appeared in 1966, quite dissimilar to the russellian of 1902 09. The title is borrowed from Eph. 5: 19: "Singing and accompanying yourselves with music in your hearts" (Swedish edition with the same title translated in 1969). All hymns are tuned in the major key and have mostly the character of war songs, e.g.:

God's army is advancing:

its ev'ry pow'r it bends

to honor him, Jehovah, and keep all his commands.

What tho' the great red dragon

assails God's army small,

the shadow of his own hand

securely guards them all.

(Nr. 16: 1, cf. 90: 1: "See Jehovah's army!")

Hail the Theocracy, ever increasing!

Wondrous expansion is now taking place...

or the chorus:

(Nr. 27:1)

Then let's go forth! Bravely press on!

Advancing truth be our light.

Thus says Jehovah: "I'll strengthen and help you;

battle for truth and for right!"'

(Nr. 33)

Instead of calculating dates in the future (which Russell did not in the hymns either), a song e.g. runs as follows:

The "signs of the times" prove God's rule has begun.

In glory enthroned sits Jehovah's Son.

The battle in heaven he's fought and won, and soon on the earth shall God's will be done.

(Nr. 93:1)

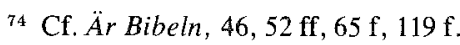

${ }^{75}$ Cf. ib. 14, 16, 51, 65, 105, 125. 
Jesus is hardly mentioned. He is not the good Shepherd: "Jehovah God is my Shepherd;/ So why should I fear or fret?" (Nr. 41:1). Only in passing we hear:

You were the first to love us;

your love thru Christ does move us

to love you in return from our hearts.

To sanctify your name and

reveal your love, Christ came, and

eternal life he thereby imparts.

(Nr. 23:2)

In the preceding paper there has been pointed to great differences between the three periods. Professor Efraim Briem was quite wrong when he wrote: "The work is carried on in the old footsteps with unceasing repetition of all Russel's and Rutherford's doctrines and fancies." ${ }^{\prime 6}$ Neither doctrine nor fancy is the same.

What, then, about the ideas of the future and time's end? The faith in the battle at Harmageddon is still alive. But an interview in 1956 with the "Land Servant of Sweden", Johan Henrik Eneroth, is very illusive:

" - What do you expect to happen in 1975 ?

- We don't know. But we know that at that time 6000 years have passed since the creation of Adam on the sixth day [...] The seventh day must be quite as long as the preceding days of creation, viz. 7000 years. " 77

Today we have, according to that message, probably 7001 years left.

\section{Bibliography}

All Scripture, 1963, "All Scripture Is Inspired of God and Beneficial". Brooklyn, N.Y. Babylon, 1963, "Babylon the Great Has Fallen!" God's Kingdom Rules! Brooklyn, N.Y. Briem, E., 1944, Jehovas vittnen. Stockholm.

Gott verk, 1954, "Till allt gott verk skicklig". Brooklyn, N.Y.

Guds rike, 1974, Guds tusenåriga rike har kommit nära. Wiesbaden.

Hoekema, A., 1969, The Four Major Cults. Exeter.

Hymns, 1902, Hymns of Dawn. Poem and Hymns of Dawn. Allegheny, Pa.

- 1909, Hymns of Dawn. Hymns of the Millennial Dawn. London.

Knorr, N., 1948, Jehovah's Witnesses. Religion in the Twentieth Century. New York.

Lăt Gud, 1950, "Làt Gud vara sannfärdig"'. Brooklyn, N.Y.

- 1963, "Låt Gud vara sannfärdig". Brooklyn, N.Y.

McKinney, G., 1962, The Theology of the Jehovah's Witnesses. Grand Rapids, Mich.

${ }^{76}$ Briem, 71.

${ }^{77}$ Persson, $63 \mathrm{f}$. 
Morgonsånger, 1909, Morgonsånger. Örebro.

- 1921, Morgonsånger. Örebro.

Paradiset, 1961, Från det förlorade paradiset till det återvunna paradiset. Brooklyn, N.Y.

Ringgren, H., Ström, A., 1967, Religions of Mankind. Philadelphia, Pa.

Russell, C., 1954, Studies in the Scriptures 1-6. East Rutherford, N.J.

- 1921, Studier i Skriften 7. Örebro.

Rutherford, J., 1916, Oration at Evening Service. The Watch Tower 37.

- 1923, Guds harpa. Örebro.

- 1926, Befrielse. Brooklyn, N.Y.

- 1929, Profetiorna. Brooklyn, N.Y.

- 1930, Ljus 1-2. Brooklyn, N.Y.

- 1931 a, Skapelsen. Magdeburg.

- 1931 b. Framtidens regering. Magdeburg.

- 1932, Beskydd och räddning. Bern.

- 1938, Rikedom. Bern.

- 1941 a, Herradömet och freden. Bern.

- $1941 b$, Teokratien - den enda tillftykten. Stockholm.

- 1942, Religion. Helsingfors.

Singing, 1966, "Singing and accompaying yourselves with music in your hearts". Brooklyn, N.Y.

Skaffa eder, 1957, "Skaffa eder visshet i fråga om alla ting". Brooklyn, N.Y.

Skjerpe, O., 1971, Jehovas vittnen och vad de lär. Stockholm.

Ståhl, B., Persson, B., 1970, Kulter, sekter, samfund. Solna.

Ström, A., 1946, Religion och gemenskap. Uppsala.

- 1969, Red Indian Elements in Early Mormonism. Temenos 5.

Utsagor, 1966, "Utsagor, i vilka Gud omöjligen kunde ljuga". Brooklyn, N.Y.

What Has Religion, 1951, What Has Religion Done for Mankind? Brooklyn, N.Y.

Your Will, 1958, "Your Will Be Done Ort Earth". Brooklyn, N.Y.

Är Bibeln, 1969, Är Bibeln verkligen Guds ord. Wiesbaden. 